\title{
"Ikäihmisten ohjausta ja oppimista on Suomessa tutkittu yllättävänkin vähän”
}

\author{
Rovaniemeläinen kasvatustieteen apulaisprofessori Päivi Rasi, \\ 52, innoittuu opettamisesta ja kävelemisestä. Kumpikin on \\ ehtymätön tutkimusideoiden lähde.
}

MINUSTA TULI TUTKIJA oikeastaan jo opiskeluaikanani Tampereen yliopistossa 1990-luvulla. Opiskelin sosiaalipsykologiaa, psykologiaa, sosiologiaa ja aikuiskasvatusta, ja yliopistomaailma tuntui omaltani. Pääsin kirjoittamaan gradustani artikkelin Gaudeamuksen kirjaan Naiset ja ikääntyminen, mikä sekin jälkikäteen ajateltuna oli urani kannalta merkittävä kokemus.

Valmistumiseni tiimoilla työskentelin kuusi vuotta aikuisten opetus- ja ohjaustehtävissä avoimessa yliopistossa, kansanopistossa, aikuislukiossa ja urheiluseurassa. Opetin suurella innolla yliopistossa opiskelemiani tieteenaloja ja kaikenlaista muutakin, mukaan lukien rullaluistelua ja tiffanytöitä. Kiinnostukseni opetuksen ja oppimisen tieteellisiin kysymyksiin lisääntyi entisestään. Erityisesti intoani lisäsi työskentely Rovaniemen aikuislukiossa, jonka silloinen rehtori Marjatta Rautiainen kehitti edelläkävijänä määrätietoisesti verkko-opetusta ja kannusti tutkimusperustaisuuteen.

2000-luvun alussa pääsin töihin Lapin yliopiston Mediapedagogiikkakeskukseen (MPK). Sen tutkimus- ja kehittämishankkeissa väittelin kasvatustieteen tohtoriksi ja kasvoin tutkijaksi. Aikuiskasvatuksen alan väitöskirjani käsitteli digitaalisia videoita ja videotuottamista osana opetusta ja oppimista. Työskentelen

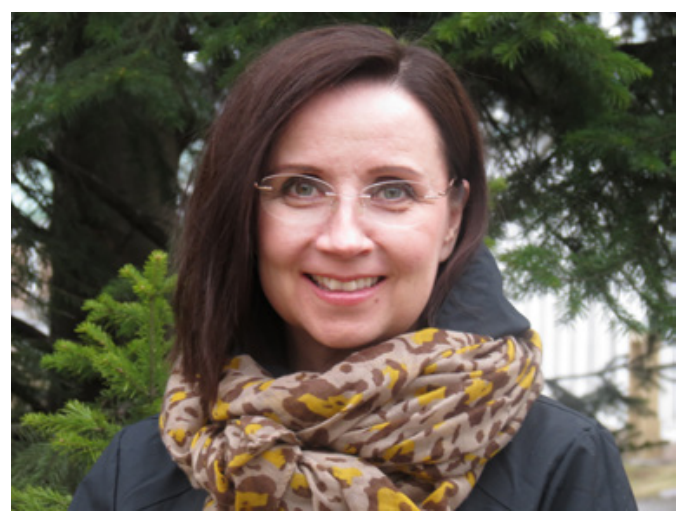

Mediakasvatuksen tutkija Päivi Rasi osoittaa tuoreessa sosiaalipsykologian väitöstutkimuksessaan, että ikääntyneet asemoidaan puutteellisten taitojensa ja rajallisen internetin käyttökokemuksensa takia digitalisaation marginaaliin.

edelleen samassa yksikössä, joka nykyisin tunnetaan Media Education Hubina. Tutkimustyön monipuolisuus, vaativuus ja luovuus innostavat yhä. Ihan parasta on, kun aineistosta alkaa pitkällisen työskentelyn jälkeen hahmottua tuloksia, sanottavaa maailmalle.

JOS EN TUTKISI, toimisin opetus- ja kehittämistehtävissä. Vaikka lähdin opetustöihin sattumalta, en näe muita vaihtoehtoja. Olen opettanut lähes 25 vuotta, 


\section{TUTKIJAN YHTEISKUNNALLINEN VASTUU ON ANTAA ARVOA MUILlE TUTKIJOILLE JA ERI ALOJEN TOIMIJOILLE.}

alkuaikoina enemmän, nykyään selvästi vähemmän. Aina se on kuitenkin tuntunut pääosin luontevalta, innostavalta ja palkitsevalta - oppimiskokemukselta itsellenikin. Kehittämishankkeet selkeine tavoitteineen ja aikatauluineen ovat myös aina innostaneet.

AIKUISKASVATUSTIEDETTÄ TARVITAAN YHTEISKUNNASSA lisäämään ymmärrystä aikuisista ja ikäihmisistä osana yhteiskuntaa - niin oppimisen, osallisuuden kuin hyvinvoinninkin näkökulmista. Lisäksi aikuiskasvatustiedettä tarvitaan, jotta osallistujille voidaan tarjota yhdenvertaisesti ohjausta ja tukea oppimiseen heille merkityksellisissä asioissa. Näen tulevaisuudessa tärkeänä ikäihmisten oppimisen ja osallisuuden kysymykset, erityisesti digitalisaation näkökulmasta. Ikähmisten ohjausta ja oppimista on Suomessa tutkittu yllättävänkin vähän.

PARAIKAA TUTKIN ikäihmisten medialukutaitoja ja digitaalista osaamista ja niitä koskevan ohjauksen kysymyksiä. Tutkimukseni kytkeytyy sekä aikuiskasvatukseen että mediakasvatukseen. Sain juuri painosta toisen väitöskirjani, joka on sosiaalipsykologian alalta. Selvitin, kuinka ikäihmisten suhteet internetiin rakentuvat sosiaalisesti Suomen harvaan asutuimmilla alueilla Lapissa, Kainuussa ja Pohjois-Pohjanmaalla. Päätulokseni on, että ikäihmiset asemoidaan puutteellisten taitojensa, rajallisen internetin käyttönsä tai käyttämättömyytensä takia digitalisaation marginaaliin.

NOJAAN TUTKIMUSTYÖSSÄNI TEORIOIHIN, joiden keskiössä ovat ihmisten tulkinnat todellisuudesta ja merkitykset, joita he ilmiöille ja tapahtumille antavat. Oppimisen tutkimuksessa olen hyödyntänyt muun muassa mielekkään oppimisen näkökulmia siten kuin etenkin David Ausubel ja David Jonassen ovat niitä kehitelleet. Sosiaalipsykologiassa olen nojannut tulkinnalliseen sosiaaliseen konstruktionismiin, kuten Serge Moscovicin sosiaalisten representaatioiden teoriaan.

SEURAAVAKSI HALUAN jatkaa tutkimusta ikäihmisten medialukutaidoista ja oppimisesta. Olen suunnitellut panostavani siihen jäljellä olevan työurani. Aihepiiri tuntuu mielekkäältä, sillä samanaikaisesti ikäännyn itsekin.

KOLLEGOILTANI SAAN valtavasti tukea tutkimustyöhöni: vinkkejä tulevista rahoitushauista, hyvistä julkaisuista tai työtä helpottavista sovelluksista. He mallintavat tutkijan taitoja, heiltä voi oppia. Kollegat tukevat vaikeissa paikoissa, kuten kielteisten rahoituspäätösten äärellä. Tutkijan työ on hyvinkin yhteisöllistä, julkaisuja kirjoitetaan pääosin yhdessä. Alkuajoista kollegaverkostoni ovat kansainvälistyneet huimasti.

KUN EN TUTKI, pyöritän arkea kahden tyttären lähivanhempana. Vietän aikaani pääosin heidän ja avopuolisoni kanssa, joka vie minut rock'n'rollin maailmaan. Liikuntaharrastuksista voi todeta, että muut menevät ja tulevat, mutta kävely pysyy. Usein tutkimusideat syntyvät kävellessä.

\section{Klassikko, johon palaan}

Edesmenneen sosiaalipsykologian professorin Antti Eskolan tuotantoon palaan aika ajoin. Erityisesti teos Vuorovaikutus, muutos, merkitys (Tammi 1982) herätti aikanaan kiinnostukseni merkitysten tutkimiseen. Minulla oli myös kunnia olla yksi Antin ohjattavista Tampereen yliopistossa.

Sarja vie aikuiskasvatuksen tutkijan arkeen ja verkostoihin. Sen tuottaa Aikuiskasvatuksen Tutkimusseura. 